\title{
Recurrent Anaplastic Large Cell Lymphoma
}

National Cancer Institute

\section{Source}

National Cancer Institute. Recurrent Anaplastic Large Cell Lymphoma. NCI Thesaurus.

Code C9250.

The reemergence of anaplastic large cell lymphoma after a period of remission. 